\title{
PENGARUH KOMITMEN PROFESI, SOSIALISASI ANTISIPATIF MAHASISWA AKUNTANSI DAN ETHICAL CLIMATE PRINCIPLE TERHADAP NIAT WHISTLEBLOWING
}

\author{
Satya Wahyu ${ }^{1}$, Hadi Mahmudah ${ }^{2}$ \\ 1,2 Universitas Islam 45 \\ Jln. Cut Mutia Raya No. 83, Margahayu, Bekasi Timur \\ E-mail : hadimahmudah@gmail.com
}

\begin{abstract}
Whistleblowing is one of the company's internal control mechanisms. In practice many employees do not want to report fraud that occurred in the company. This study examines the influence of professional commitment, anticipatory socialization of accounting students and ethical climate principle towards whistleblowing intentions. The sample of this research is 6th semester accounting student in Jabodetabek which amounts to 125. Data is processed using multiple regressions. The results showed that professional commitment, anticipatory socialization of accounting students and ethical climate principle influenced the intention of whistleblowing.
\end{abstract}

Keywords: whistleblowing, professional commitment, anticipatory socialization, and ethical climate principle

\section{PENDAHULUAN}

Akhir-akhir ini masalah mengenai whistleblowing semakin ramai dibicarakan. Banyaknya pembicaraan mengenai whistleblowing ini tidak lepas dari banyaknya kasus-kasus besar yang terungkap dari seorang whistleblower. Kasus whistleblowing di tingkat dunia adalah kasus enron sedangkan kasus di Indonesia contohnya adalah kasus Pol. Susno duaji yang menyeret pegawai kementrian pajak. Dari beberapa kasus ini membuktikan bahwa peran whistleblowing ini sangatlah besar dalam rangka mencegah atau mengungkap suatu tindakan ilegal yang terjadi di dalam organisasi.

Selain dari contoh kasus ini peranan seorang whistleblowing dalam mencegah kecurangan juga sudah banyak di teliti di seluruh negara, antara lain hasil penelitian oleh Sweeney (2008). Namun menjadi whistleblower bukanlah perkara yang mudah. Hal ini tidak terlepas dari banyaknya resiko yang harus dihadapi seorang whistleblower ini, dari ancaman orang yang merasa dirugikan sampai ancaman perlawanan jalur hukum dari seorang yang merasa dirugikan. Tidak jarang seorang whistleblower ini berbalik menjadi tersangka. Hal ini dikarenakan sistem pelaporan dan perlindungan bagi whistleblower yang belum efektif. Dari hasil survei ini membuktikan bahwa banyak sekali karyawan yang mengetahui tindakan kecurangan namun tidak mau melaporkan tindakan kecurangan ini. Banyak faktor kenapa seorang tidak melaporkan pelanggaran antara lain karena takut oleh ancaman yang akan di terima dan juga karena tidak tahunya kemana mereka harus melapor.

Ethical climate sendiri terdiri dari tiga kriteria yaitu Egoism (memaksimalkan kepentingan sendiri), Benevolence (memaksimalkan kepentingan bersama) dan Principle (prinsip) (Cullen dkk.,1993).

Iklim etika prinsip dari penelitian sebelumnya memiliki pengaruh seignifikan terhadap niat melakukan whistleblowing. Ahmad dkk. (2014) menjelaskan bahwa iklim prinsip yang 
Jurnal Ilmiah Ekonomi dan Bisnís

Vol. 15. No. 2, September 2018: 165-176

EISSN : $2442-9813$

ISSN : 1829-9822

dianut oleh auditor internal terbukti lebih berpengaruh dari pada Egoism dan Benevolence. Penelitian ini bertujuan untuk menguji pengaruh komitmen profesi, sosialisasi antisipatif mahasiswa akuntansi dan ethical climate principle terhadap niat whistleblowing.

\section{TINJAUAN PUSTAKA}

Penelitian ini merupakan pengembangan dari penelitian Elias (2008) dan Merdikawati (2012) mengenai hubungan komitmen profesi dan sosialisasi antisipatif terhadap whistleblowing. Penelitian sebelumnya membuktikan bahwa komitmen profesi memiliki hubungan dengan niat whistleblowing.

Hasil penelitian sebelumnya telah menjelaskan bahwa tingkat komitmen profesional mempengaruhi landasan etis seseorang sehingga terdapat kemungkinan seseorang yang berkomitmen terhadap profesinya memiliki kecenderungan yang lebih tinggi untuk melakukan whistleblowing (Elias, 2008).

Sosialisasi antisipatif, dalam penelitian sebelumnya membuktikan bahwa tingkat sosialisasi antisipatif memiliki hubunngan dengan niat untuk melakukan whistleblowing. Sosialisasi antisipatif merupakan tingkat pemahaman seseorang terhadap sikap dan kepercayaan profesi yang digeluti (Merdikawati, 2012). Sehingga seseorang dengan level sosialisasi antisipatif yang tinggi akan mengetahui tindakan yang harus dan tidak seharusnya dilakukan oleh profesinya (Merdikawati, 2012). Seseorang yang memiliki sosialisasi antisipatif yang tinggi akan cenderung mematuhi kode etik profesinya dan akan cenderung memiliki niat melakukan whistleblowing, karena ia tau tindakan kecurangan itu melanggar kode etik profesi.
Selain meneliti hubungan komitmen profesi dan sosialisasi antisipatif, penelitian ini menambahkan variabel dari faktor organisasi yaitu ethical climate (iklim etis). Alasan penambahan faktor organisasi karena menurut Miceli (1984) menunjukan bahwa pengaruh konteks organisasi lebih banyak menentukan keputusan seorang whistleblower.

Penelitian mengenai hubungan Iklim etis terhadap niat whistleblowing sebelumnya menunjukan bahwa iklim etis prinsip menunjukan pengaruh yang signifikan terhadap niat melakukan whistleblowing. Namun hasil yang berbeda mungkin saja terjadi jika dilakukan penelitian di organisasi yang berbeda, yang memiliki iklim etis yang berbeda pula. Hal ini dikarenakan setiap organisasi memiliki iklim prinsip, dan karyawan akan mempertimbangkan penerapan aturan, prinsip-prinsip dan hukum dalam membuat keputusan etis mereka (Ahmad dkk., 2014).

Dari penjelasan di atas maka kerangka berpikir ini dapat di gambarkan sebagai berikut :

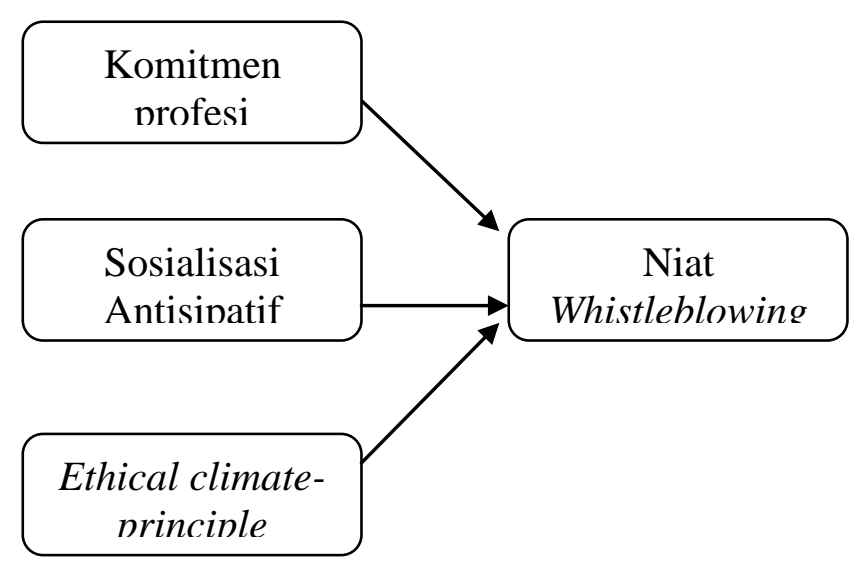

Pengembangan hipotesis

Pengaruh komitmen profesi terhadap niat whistleblowing

Sesuai dengan Theory of Planned Behavior perilaku seseorang akan dipengaruhi oleh niat seseorang, dan niat 
ini akan dipengaruhi oleh sikap terhadap perilaku. Elias (2008) dan Merdikawati (2012) melakukan penelitian kepada mahasiswa terhadap niat melakukan whistleblowing dan hasil penelitiannya menunjukan mahasiswa dengan tingkat komitmen profesi yang tinggi memandang whistleblowing sebagai hal yang penting dan memiliki kecenderungan untuk melakukan whistleblowing.

Elias (2006) menemukan bahwa mahasiswa yang lebih senior memiliki level komitmen profesi yang lebih tinggi. Tingkat komitmen profesi ini dipengaruhi oleh semakin pahamnya mahasiswa yang lebih senior akan pentingnya laporan keuangan dan pentingnya menjaga dan mematuhi kode etik profesi.

Tingkat komitmen dan tingkat pemahaman mahasiswa ini nantinya yang akan mempengaruhi sikap mereka terhadap tindakan kecurangan dan pentingnya menjaga kode etik profesi, dan sikap terhadap perilaku ini nantinya yang akan mempengaruhi niat seseorang terhadap perilaku. Berdasarkan hal tersebut peneliti memiliki dugaan ada pengaruh antara level komitmen profesi mahasiswa terhadap niat melakukan whistleblowing, sehingga hipotesis yang akan diajukan adalah :

H1: Komitmen profesi berpengaruh terhadap niat melakukan whistleblowing.

Pengaruh sosialisasi antisipatif terhadap niat whistleblowing

Perbedaan tingkat pemahaman akan suatu hal akan berpengaruh pada sikap yang mereka berikan, dan sikap ini akan mempengaruhi terhadap niat yang akan di ambil seseorang. Begitu pula dengan profesi akuntan, tingkat pemahaman yang berbeda mengenai aturan, undang-undang, maupun kode etik profesi ini akan berpengaruh terhadap sikap yang mereka berikan dalam menilai suatu hal, misalnya dalam kasus kecurangan. Sehingga sosialisasi antisipatif ini penting dilakukan sebelum orang itu masuk ke lingkungan kerja yang seseungghnya.

Penelitian sebelumnya yang dilakukan Elias (2008) dan Merdikawati (2012) menunjukan tingkat sosialisasi antisipatif mahasiswa memiliki hubungan signifikan dengan niat melakukan whistleblowing. Artinya mahasiswa dengan tingkat sosialisasi antisipatif tinggi akan cenderung memiliki niat melakukan whistleblowing.

Mahasiswa dengan tingkat sosialisasi antisipatif yang tinggi memiliki pemahaman yang tinggi pula mengenai undang-undang, peraturan apa saja yang diperboleh dan tidak diperbolehkan oleh profesinya, dan juga pemahaman akan apa saja yang melanggar kode etik profesinya. Sehingga mahasiswa dengan sosialisasi antisipatif yang tinggi akan memandang tindakan kecurangan atau fraud ini merupakan tindakan yang melanggar aturan dan juga kode etik profesi, sehingga mahasiswa dengan tingkat sosialisasi antisipatif yang tinggi akan cenderung memiliki niat untuk melakukan whistleblowing. Berdasarkan hal tersebut hipotesis yang diajukan peneliti adalah :

$\mathrm{H} 2$ : Sosialisasi antisipatif berpengaruh terhadap niat melakukan whistleblowing

Pengaruh Ethical Climate-principle terhadap niat melakukan whistlebowing

Sesuai dengan Theory of Planned Behavior selain sikap terhadap perilaku, norma subyektif (subjective Norm) memiliki pengaruh terhadap niat seseorang terhadap perilaku. Ini artinya penilaiaan orang lain mengenai baik, buruk, diterima atau tidak diterima terhadap perilaku yang akan kita lakukan akan menjadi salah satu dasar kita untuk menentukan suatu tindakan. Pemahaman mengenai perilaku yang dapat dan tidak 
Jurnal Ilmiah Ekonomi dan Bisnís

Vol. 15. No. 2, September 2018: 165-176

EISSN : $2442-9813$

ISSN : $1829-9822$

dapat diterima ini disebut dengan ethical climate (iklim etis). Menurut Sukrisno (2009) ethical climate adalah pemahaman tidak terucap dari semua karyawan (pelaku bisnis) tentang perilaku yang dapat diterima dan tidak dapat diterima.

Penelitian sebelumnya yang dilakukan oleh Ahmad (2014) terhadap auditor internal di Malaysia menunjukan bahwa ethical climateprinciple terbukti lebih berpengaruh dari pada dimensii egoism dan benevolence. Hasil yang sama juga ditunjukan Setyawati (2015) yang melakukan penelitian serupa dengan pegawai yang bekerja di berbagai unit kerja di Lembaga Kebijakan Pengadaan Barang / Jasa Pemerintah (LKPP) sebagai objek penelitiannya.

\section{Ethical}

climate-principle

didasarkan pada keyakinan bahwa ada prinsip-prinsip universal seperti aturan, hukum, dan standar. Apa bila terdapat anggota organisasi bertindak tidak etis, maka anggota lain akan terdorong untuk melakukan hal yang sebaliknya, sehingga ketaatan terhadap hukum dan kode etik merupakan faktor pertimbangan dominan bagi individu dalam menentukan dilema etis (Setyawati,2015). Sehingga dalam organisasi dengan peraturan dan hukum yang tinggi akan mengangap bahwa whistleblowing merupakan tindakan etis yang menyangkut dan membantu orang banyak. Dengan demikian dapat diduga bahwa ethical climate-principle memiliki pengaruh terhadap niat melakukan whistleblowing, sehingga hipotesis yang diajukan adalah :

H3 : Ethical Climate-Principle berpengaruh terhadap niat melakukan whistleblowing.

\section{METODE PENELITIAN}

Jenis penelitian yang digunakan adalah penelitian kuantitatif. Definisi Dan Pengukuran Variabel Niat Whistleblowing

Whistleblowing merupakan tindakan pelaporan pelanggaran yang dilakukan oleh individu yang termasuk sebagai anggota organisasi (yang masih terhitung aktif maupun tidak) kepada pihak di dalam ataupun diluar organisasi yang dapat mempengaruhi tindak kecurangan (Miceli, 1984).

Dalam penelitian ini menggunakan dua aspek dari whistleblowing yaitu persepsi whistleblowing dan keinginan whistleblowing (whistleblowing intention) (Yulianto, 2015). Pengukuran niat melakukan whistleblowing dalam penelitian ini akan menggunakan satu skenario kasus, yang berkaitan dengan akuntansi yang dikembangkan Schultz dkk. (1993).

Skenario kasus merupakan bagian yang disajikan pertama kali di dalam kuesioner. Skenario kasus menceritakan tentang seorang akuntan yang menemukan kecurangan yang dilakukan secara sengaja oleh manajemen. Dalam sekenario kasus responden akan diminta memberikan tanggapan mengenai persepsinya terhadap tingkat keseriusan kasus, tingkat tanggung jawab dalam melaporkan kasus tersebut, dampak risiko pribadi whistleblower, selain itu juga akan di ukur mengenai niat whistleblowing, dengan mengasumsikan responden sebagai karyawan yang menyadari adanya tindakan-tindakan yang mencurigakan dalam kasus tersebut. Penilaian dilakukan menggunakan skala Likert tujuh poin. Poin 1 mempresentasikan "Rendah" dan poin 7 mempresentasikan "Tinggi". Tiap Penilaian mengenai niat whistleblowing akan menggunakan tujuh skala Likert dimana poin 1 mempresentasikan "Tidak Pernah" dan poin 7 mempresentasikan "Selalu". 
Komitmen Profesi

(2008) mendefinisikan komitmen profesional sebagai suatu kecintaan yang dibentuk oleh seorang individu pada profesinya, meliputi sesuatu yang dipercaya, sesuatu yang diterima, tujuan dan nilai-nilai dari suatu profesi. Pengukuran variabel komitmen profesi dalam penelitian ini akan menggunakan lima pertanyaan yang dikembangkan Dwyer dkk. (2000) dari skala Aranya dkk. (1981).

Dwyer melakukan penyederahanaan dan pengembangan dari skala Aranya dkk. (1981) karena pada penelitian-penelitian sebelumnya mengindikasikan bahwa skala Aranya $d k k$. (1981) dapat mengandung faktorfaktor yang belum teridentifikasi seperti niat untuk tetap menekuni profesi yang dijalani saat ini (Bline $d k k ., 1997$ dalam Elias, 2008). Penilaian ini menggunakan 5 pertanyaan dan setiap pernyataan dalam penelitian ini menggunakan skala Likert 1 sampai 7 , yaitu skala 1 berarti sangat tidak setuju dan skala 7 adalah sangat setuju.

\section{Sosialisasi Antisipatif}

Sosialisasi antisipatif adalah
proses mengadopsi sikap dan kepercayaan dari sebuah kelompok sebelum seseorang menjadi bagian dari kelompok tersebut (Merton dan Rossi, 1968 dalam Elias, 2008).

Pengukuran mengenai tingkat sosialisasi antisipatif mahasiswa menggunakan sebelas pertanyaan yang dikembangkan oleh (Clikeman \& Henning, 2000). Persepsi mengenai pentingnya laporan keuangan dijadikan proxy untuk melihat seberapa besar tingkat sosialisasi antisipatif mahasiswa, karena tanggung jawab terhadap pengguna laporan keuangan merupakan norma utama yang menunjukkan profesionalisme akuntan (Merdikawati, 2012).
Dari sebelas pertanyaan ini terdiri dari empat faktor yaitu misstate, disclosures, cost-benefit, dan responsibility. Misstate digunakan untuk mengukur keinginan mahasiswa untuk melaporkan laporan keuangan secara tidak tepat. Disclosure digunakan untuk mengukur kepercayaan mahasiswa bahwa perusahaan harus mengungkapkan informasi yang lebih kepada pengguna laporan keuangan. Cost-benefit mengindikasikan keyakinan mahasiswa bahwa pelaporan keuangan jauh lebih memiliki manfaat daripada biaya yang harus dibayar. Responsibility mengindikasikan keyakinan mahasiswa bahwa manajer bertanggung-jawab atas keakuratan pelaporan. Sebelas item pernyataan ini disajikan secara acak setelah pernyataan komitmen profesi dan diukur menggunakan tujuh skala Likert. Poin 1 mempresentasikan "Sangat Tidak Setuju" sedangkan poin 7 mempresentasikan "Sangat Setuju"

\section{Ethical Climate-Principle}

Ehical climate (Iklim Etis) adalah pemahaman tidak terucap dari semua karyawan (pelaku bisnis) tentang perilaku yang dapat dan tidak dapat diterima (Sukrisno, 2009). Teori iklim etika (ethical climate theory) pertama diusulkan oleh Cullen dkk. (1987) dimana dalam teorinya Cullen dkk.(1987) membagi kriteria etis menjadi tiga dalam pembuatan keputusan yaitu Egoism (memaksimalkan kepentingan sendiri), Benevolence (memaksimalkan kepentingan orang lain) dan Principle (prinsip).

Namun dalam penelitian ini hanya akan menggunakan faktor principle dalam menentukan keputusan. Ethical climateprinciple didasarkan pada keyakinan bahwa ada prinsip-prinsip universal seperti aturan, hukum, dan standar, sehingga ketaatan terhadap hukum atau kode etik merupakan faktor pertimbangan dominan bagi individu dalam 
Jurnal Ilmiah Ekonomi dan Bisnís

Vol. 15. No. 2, September 2018: 165-176

EISSN : $2442-9813$

ISSN : 1829-9822

memutuskan, menentukan dan memilih dilema etis (Setyawati,2015).

Pengukuran ethical climateprinciple dalam penelitian ini akan menggunakan lima pertanyaan yang dikembangkan Cullen dkk. (1993). Kelima pertanyaan disajikan pada bagian terakhir dan diukur menggunakan tujuh skala Likert. Poin 1 mempresentasikan "Sangat Tidak Setuju" sedangkan poin 7 mempresentasikan "Sangat Setuju".

Teknik pengumpulan data dengan menggunakan kuesioner. Kuesioner yang disebar dalam penelitian ini sebanyak 150 kuesioner manual dan 50 kuisioner online. Untuk peenyebaran kuesioner manual dengan mendatangi langsung ke beberapa Universitas di Bekasi dan Jakarta, sedangkan untuk kuesioner online di sebarkan melalui media sosial. Waktu penyebaran kuesioner yang bertepatan dengan bulan puasa dan juga UAS menjadi salah satu kendala dalam penyebaran kuesioner.

Teknik analisis data dengan menggunakan teknik kuantitatif menggunakan alat analisis regresi linier berganda.

\section{HASIL DAN PEMBAHASAN}

Dari kuesioner yang disebarkan terkumpul 103 kuesioner manual dan 28 kuisioner online. Namun terdapat beberapa kuesioner manual yang tidak memenuhi syarat untuk di lakukan penelitian dikarenakan tidak adanya identitas dan adanya jawaban yang tidak diisi, adapun kuesioner manual yang memenuhi syarat sebanyak 97 kuesioner. Sehingga jumlah kuesioner yang dapat dilakukan penelitian sebanyak 125 kuesioner.

Uji Validitas

Untuk memperoleh data penelitian yang dapat dipercaya dan dipertanggungjawabkan secara ilmiah maka kuesioner terlebih dahulu diuji tingkat validitas dan reliabilitasnya sebelum digunakan untuk penelitian. Uji validitas dan reliabilitas dalam penelitian ini menggunakan semua data yang diperoleh yaitu sebanyak 125. Hal ini dikarenakan kuesioner ini telah dipakai peneliti sebelumnya untuk melakukan penelitian yang sama, jadi pengujian validitas dan reliabilitas kuesioner ini bersifat untuk memastikan kembali apakah kuesioner ini valid.

Untuk pengujian validitas dalam penelitian ini menggunakan spss dengan metode Bivariate Pearson ( Pearson Product moment) dimana kaidah keputusan uji validitas ini menggunakan batasan $r$ tabel. Nilai $r$ tabel dapat diketahui dari tabel $\mathrm{r}$ product moment tingkat signifikasi 0,05 (two tail) dengan sample 125 yaitu sebesar 0,176 , sehingga jika nilai $r$ hitung lebih besar dari $r$ tabel maka item pertanyaan valid. Hasil pengujian validitas setiap item variable dalam penelitian ini valid.

Uji reliabilitas

Dari hasil pengujian menunjukan bahwa semua variabel memiliki nilai Cronbach's Alpha >0,60. Variabel Whisleblowing memiliki nilai Cronbach's Alpha sebesar 0,736; komitmen profesi sebesar 0,719; variabel sosialisasi antisipatif dengan proksi persepsi laporan keuangan yang diturunkan menjadi 4 faktor masing-masing yaitu faktor misstate sebesar 0,628; disclosure 0,690; cost-benefit 0,655 ; dan responsibility sebesar 0,646; dan variabel ethical climate-principle memiliki nilai Cronbach's Alpha sebesar 0,738.

Analisis Regresi linier berganda

Uji analisis regresi linier berganda digunakan dengan cara melibatkan tiga variabel bebas (Komitmen profesi, Sosialisasi Antisipatif, Ethical climateprinciple) dan variabel terikat (Niat Whistleblowing). Cara ini digunakan untuk mengetahui kuatnya pengaruh 
antara beberapa variabel bebas secara serentak terhadap variabel terikat. Data yang akan diuji dalam pengujian regresi berganda adalah skor hasil kuesioner. Selanjutnya, hasil pengujian regresi berganda dengan menggunakan program SPSS dapat dilihat pada Tabel 4.8 berikut ini:

tersebut menunjukkan bahwa model persamaan regresi linear berganda untuk memperkirakan niat whistleblowing yang dipengaruhi oleh komitmen profesi, sosialisasi antisipatif, dan ethical climate-principle adalah :

$\mathrm{Y}=6,303+0,156\left(\mathrm{X}_{1}\right)+0,093\left(\mathrm{X}_{2}\right)+$ $0,171\left(\mathrm{X}_{3}\right)$

Hasil Uji analisis regresi linier berganda tersebut dapat diartikan sebagai berikut:

1. Angka koefisien konstanta (a) = 6,303 artinya jika tidak ada variabel komitmen profesi, sosialisasi antisipati, dan ethical climate-principle maka niat whistleblowing mahasiswa akutansi sebesar 6,303 satuan.

2. Angka koefisien komitmen profesi $\left(b_{1}\right)=0,156$ (bernilai positif) artinya setiap terjadi penambahan satu satuan variabel komitmen profesi, akan meningkatkan niat whistleblowing sebesar 0,156 satuan.

3. Angka koefisien sosialisasi antisipatif $\left(b_{2}\right)=0,093$ (bernilai positif) artinya setiap terjadi penambahan satu satuan variabel sosialisasi antisipatif, akan meningkatkan niat whistleblowing sebesar 0,093 satuan.

4. Angka koefisien ethical climateprinciple $\left(b_{3}\right)=0,171$ (bernilai positif) artinya setiap terjadi penambahan satu satuan ethical climate-principle, akan meningkatkan niat whistleblowing

sebesar

0,171

satuan.

Uji F

Uji $\mathrm{F}$ digunakan untuk melihat kesesuaian model regresi yang telah dibuat apakah layak untuk digunakan atau tidak. Adapun hasil uji $\mathrm{F}$ dapat dilihat pada tabel 4.9 Sebagai berikut :

Nilai. F hitung (sig.) pada tabel di atas memiliki nilai 0,000 lebih kecil dari tingkat signifikansi 0,05 sehingga dapat disimpulkan bahwa model regresi linier yang diestimasi layak digunakan untuk menjelaskan pengaruh komitmen profesi, sosialisasi antisipatif, ethical climate principle terhadap niat whistleblowing.

Uji $t$ pada penelitin ini digunakan untuk mengukur tingkat signifikasi pengaruh yang ditimbulkan oleh variabel bebas (komitmen profesi, sosialisasi antisipatif, ethical climate-principle) terhadap variabel terikat (niat whistleblowing) secara parsial. Adapun hasil uji t adalah sebagai berikut :

Berdasarkan tabel tersebut maka dapat disimpulkan sebagai berikut :

a. Pada koefisien konstanta (a) sebesar 6,303 diperoleh angka $\mathrm{t}$ hitung sebesar 2.127 dengan angka signifikan sebesar 0,035 (kurang dari 0,05) berarti koefisien konstanta (a) signifikan. Hal ini menunjukan koefisien konstanta (a) dapat dipakai dalam model regresi berganda untuk melakukan prediksi terhadap perubahan tingkat niat whistleblowing.

b. Pada koefisien konstanta komitmen profesi sebesar 0,156 diperoleh angka $\mathrm{t}$ hitung sebesar 2.125 dengan angka signifikan sebesar 0,036 (kurang dari 0,05) berarti koefisien komitmen profesi signifikan. Hal ini menunjukan koefisien komitmen profesi dapat dipakai dalam model regresi berganda untuk melakukan prediksi terhadap perubahan 
tingkat niat whistleblowing. Artinya, variabel komitmen profesi berpengaruh signifikan terhadap niat whistleblowing.

c. Pada koefisien konstanta sosialisasi antisipatif sebesar 0,093 diperoleh angka $t$ hitung sebesar 2,014 dengan angka signifikan sebesar 0,046 (kurang dari 0,05 ) berarti koefisien sosialisasi antisipatif signifikan. Hal ini menunjukan koefisien sosialisasi antisipatif dapat dipakai dalam model regresi berganda untuk melakukan prediksi terhadap perubahan tingkat niat whistleblowing. Artinya, variabel sosialisasi antisipatif berpengaruh signifikan terhadap niat whistleblowing

d. Pada koefisien konstanta ethical climate-principle sebesar 0,171 diperoleh angka t hitung sebesar 2,131 dengan angka signifikan sebesar 0,035 (kurang dari 0,05) berarti koefisien ethical climateprinciple signifikan. Hal ini menunjukan koefisien ethical climate-principle dapat dipakai dalam model regresi berganda untuk melakukan prediksi terhadap perubahan tingkat niat whistleblowing. Artinya, variabel ethical climate-principle berpengaruh signifikan terhadap niat whistleblowing

Penelitian ini bertujuan untuk meneliti pengaruh komitmen profesi, sosialisasi antisipatif mahasiswa akuntansi, ethical climate-principle terhadap niat whistleblowing. Adapun objek dari penelitian ini yaitu mahasiswa akuntansi yang telah mengambil mata kuliah audit dan etika profesi, dimana peneliti mengambil sampel dari mahasiswa semester 6 dan 8 di beberapa kampus dan perguruan tinggi di wilayah Jabodetabek yang di asumsikan telah mengambil mata kuliah tersebut.
Penyebaran kuesioner dalam penelitian ini terdiri dari dua cara yaitu dengan kuesioner konvensional dan juga kuesioner online. Dari hasil kuesioner yang disebarkan diperoleh 125 kuesioner yang selanjutnya dapat dilalukan uji statistik.

Hasil uji t menunjukan bahwa komitmen profesi memiliki pengaruh positif signifikan terhadap niat whistleblowing. Sesaui dengan Theory of planned behaviour bahwa perilaku dipengaruhi oleh minat terhadap perilaku dan salah satu yang mempengaruhi minat yaitu sikap terhadap perilaku. Aranya (1981) dalam Elias (2008) mendefinisikan komitmen profesional sebagai suatu kecintaan yang dibentuk oleh seorang individu pada profesinya, meliputi sesuatu yang dipercaya, sesuatu yang diterima, tujuan dan nilai-nilai dari suatu profesi, kemauan untuk berupaya sekuat tenaga demi organisasi, dan keinginan menjaga keanggotaan dari suatu profesi. Sehingga seseorang dengan tingkat komitmen yang tinggi akan beranggapan bahwa whistleblowing adalah suatu hal yang benar demi kelangsungan organisasinya.

Penelitian ini sejalan dengan penelitian yang dilakukan Hong Hong (2014), dan Jalil (2014) yang menyimpulkan bahwa komitmen profesi berpengaruh terhadap niat whistleblowing. Penelitian ini juga mendukung penelitian Elias (2008) dan Merdikawati (2014) yang mengungkapkan adanya hubungan positif dan pengaruh yang signifikan antara komitmen profesional dengan kemungkingan seseorang untuk melakukan whistleblowing.

Variabel sosialisasi antisipatif dalam penelitian ini menunjukan pengaruh positif signifikan terhadap niat whistleblowing. Sesuai dengan Theory of planned behaviour bahwa perilaku dipengaruhi oleh minat terhadap perilaku dan salah satu yang mempengaruhi minat yaitu sikap terhadap perilaku. Mahasiswa dengan tingkat sosialisasi antisipatif yang 
tinggi memiliki pemahaman yang tinggi pula mengenai undang-undang, peraturan apa saja yang diperboleh dan tidak diperbolehkan oleh profesinya, dan juga pemahaman akan apa saja yang melanggar kode etik profesinya. Sehingga mahasiswa dengan sosialisasi antisipatif yang tinggi akan memandang tindakan kecurangan atau fraud ini merupakan tindakan yang melanggar aturan dan juga kode etik profesi, sehingga mahasiswa dengan tingkat sosialisasi antisipatif yang tinggi akan cenderung memiliki niat untuk melakukan whistleblowing.

Hasil penelitian ini sejalan dengan penelitian yang dilakukan Hong Hong (2014) dan Faradisa (2017) yang menyimpulkan bahwa sosialisasi antisipatif berpengaruh terhadap niat whistleblowing. Hasil penelitian ini juga mendukung hasil penelitian yang dilakukan oleh Elias (2008) dan merdikawati (2014) yang mengungkapkan bahwa seseorang dengan sosialisasi antisipatif tinggi, mempunyai kecenderungan dalam melakukan tindakan whistleblowing dibandingkan dengan seseorang dengan sosialisasi antisipatif yang rendah .

Variabel ethical climate-principle dalam penelitian ini juga menunjukan pengaruh positif yang signifikan terhadap niat whistleblowing. Ethical climate - principle didasarkan pada keyakinan bahwa ada prinsip-prinsip universal seperti aturan, hukum, dan standar. Jika anggota organisasi terlibat dalam perilaku tidak etis, anggota lain terdorong untuk berbeda pendapat sehingga ketaatan terhadap hukum atau kode etik merupakan faktor pertimbangan dominan bagi individu dalam memutuskan, menentukan dan memilih dilema etis. Ketika sebuah organisasi mengembangkan ethical climate - principle yang tinggi, anggota organisasi akan cenderung melakukan whitleblowing (Setyawati, 2015). Hal ini juga berlaku dalam dunia akuntan dimana di dalamnnya memiliki hukum, norma, standar dan juga kode etik yang harus dijalani semua anggotanya. Sehingga ketika terjadi kecurangan ataupun tidak sesuai dengan standar yang ada, anggota organisasi akan cenderung melakukan whistleblowing.

Hasil ini sejalan dengan penelitian Ahmad (2011) dan Setyawati (2015) yang menyimpulkan bahwa ethical climateprinciple berpengaruh terhadap whistleblowing.

\section{KESIMPULAN DAN SARAN}

Tujuan dari penelitian ini untuk menguji pengaruh komitmen profesi, sosialisasi antisipatif mahasiswa akutansi , ethical climate-principle terhadap niat whistleblowing. Berdasarkan dari hasil analisis, pengujian hipotesis, dan interpretasi hasil dapat ditarik kesimpulan sebagaimana diuraikan dibawah ini:

Komitmen profesi berpengaruh positif signifikan terhadat niat melakukan whistleblowing, artinya semakin tinggi tingkat komitmen profesi mahasiswa maka semakin tinggi pula niat untuk melakukan whistleblowing.

Sosialisasi antisipatif berpengaruh positif signifikan terhadap niat melakukan whistleblowing, artinya semakin tinggi tingkat sosialisasi antisipatif mahasiswa akuntansi maka semakin tinggi pula niat untuk melakukan whistleblowing.

Ethical climate-principle berpengaruh positif signifikan terhadap niat melakukan whistleblowing. Artinya semakin tinggi tingkat ethical climateprinciple suatu organisasi maka semakin tinggi pula niat untuk melakukan whistleblowing.

Dalam melakukan penelitian ini ada beberapa keterbatasan, adapun keterbatasannya antara lain sebagai berikut: Responden dalam penelitian ini berasal dari berbagai Universitas ataupun sekolah tinggi, sehingga dalam penelitian ini tidak dapat memastikan reponden memiliki 
Jurnal Ilmiah Ekonomi dan Bisnis

Vol. 15. No. 2, September 2018: 165-176

EISSN : $2442-9813$

ISSN : 1829-9822

karakteristik dan pemahaman yang sama. Waktu penyebaran kuesioner yang kurang tepat mengakibatkan tingkat pengembalian yang kurang, dimana penyebaran kuesioner bertepatan di bulan puasa dan juga bertepatan dengan UAS. Dalam pengukuran variabel niat whistleblowing, dalam penelitian ini hanya menggunakan satu kasus yang berhubungan dengan akutansi. Dimana ini berbeda dari penelitian-penelitian sebelumnya yang menggunakan tiga kasus. Dalam penelitian ini menggunakan sampel mahasiswa, sehingga belum dapat memberi gambaran terhadap tindakan whistleblowing di dunia kerja yang sesungguhnya.

Penelitian ini memiliki

keterbatasan yang dapat diperbaiki pada penelitian-penelitian selanjutnya. Saran dan pertimbangan yang dapat digunakan antara lain: Penelitian selanjutnya sebaiknya mengontrol responden sehingga memiliki karakteristik dan tingkat pemahaman yang sama, antara lain dengan menentukan Universitas yang diteliti yang memiliki tingkat akreditasi dan kesamaan lainnya. Penelitian selanjutnya sebaiknya memperhatikan waktu penyebaran kuesioner sehingga tidak bertepatan dengan UAS ataupun dalam bulan puasa sehingga tingkat pengembalian kuesioner lebih tinggi. Penelitian selanjutnya sebaiknya menggunakan tiga kasus dalam meneliti niat whistleblowing sesuai dengan penelitian sebelumnya yang dilakukan oleh Elias (2008) dan Merdikawati (2014). Penelitian selanjutnya sebaiknya menggunakan sampel karyawan yang sudah bekerja, sehingga dapat memberikan gambaran mengenai tindakan whistleblowing di dunia kerja yang nyata.

\section{DAFTAR PUSTAKA}

Ahmad, S dkk. 2014. Whistleblowing Behaviour: The Influence of Ethical Climates Theory. Procedia-Sosial and Behavioral Science 164, 445-450.

Ajzen, I. 1991. The Theory of Planned Behavior. Organizational Behavior and Human Decision Processes Article,Vol. 50, h.179211.

Aranya,N. 1981. A Test of Holland's Theory in a Population of Accountants. Journal of Vocational Behavior 19, 15-24.

Clikeman, P. M \& Henning, S.L. 2000, The Socialization of Undergraduate Accounting Students. Issues in Accounting Education, 15(1), 1-17.

Cullen, J. B., \& Victor, B. 1993. The Ethical Climate Questionnaire an Assesment of its Development and Validity. Psychological Reports, 73(2).

Dwyer, P. D. dkk. 2000. A Research Note Concerning the Dimensionality of Profesional Commitment Scale. Behavioral Research in Accounting, 12, 279-296.

Elias, Rafik. 2008.Auditing Students' Profesional Commitment and Anticipatory Socialization and Their Relationship to Whistleblowing. Managerial Auditing Journal, Vol 23,No.3 pp.283-294.

Faradiza, S.A. \& Suci, K. C. 2017. Pengaruh Sosialisasi dan Komitmen Profesi Pegawai Pajak Terhadap Niat Whistleblowing. Jurnal Ilmu Akuntansi 
Volume 10 (1) . Yogyakarta : Universitas Teknologi

Yogyakarta.

Fauzan. 2015. Pengaruh Religiusitas dan Ethical Climate Terhadap Ethical Behavior.Jurnal Akutansi Volume 11, Nomor 3. Malang : Universitas Kanjuruhan Malang.

Hong Hong. 2014. Pengaruh Komitmen Profesi dan Sosialisasi Antisipatif Mahasiswa Profesi Akutansi Terhadap Niat Whistleblowing. Skripsi. Surabaya : Universitas Katolik Widya Mandala.

Irvandly, Pratana. 2014. Pengaruh Penerapan Whistleblowing System Terhadap Pencegahan Kecurangan (Studi Survey pada PT Coca-Cola Amatil Indonesia SO Bandung). Skripsi. Bandung : Universitas Widyatama

Jalil, Fitri Yani. 2014. Pengaruh Komitmen Profesional Dan Sosialisasi Antisipatif Mahasiswa Audit Terhadap Perilaku Whistleblowing. Jurnal Bisnis dan Manajemen, Vol.4,No.2. Jakarta : Universitas Islam Negeri Syarif Hidayatullah Jakarta

KNKG.2008. Pedoman Sistem Pelaporan Pelanggaran-SPP

(Whistleblowing WBS). System.Jakarta.

Merdikawati, Risti. 2012. Hubungan Komitmen Profesi dan Sosialisasi Antisipatif Mahasiswa Akuntansi Dengan Niat Whistleblowing. Skripsi. Semarang: Universitas Diponegoro.

Miceli, M. P. 1984. The Relationships Among Beliefs, Organizational
Position, and Whistle-Blowing Status: A Discriminant Analysis1 MARCIA, 27(4), 687-705.

Naomi, Sharon. 2015. Penerapan Whistleblowing System Dan Dampaknya Terhadap Fraud. Skripsi. Lampung : Universitas Lampung

Saranela, Merry Christslina.2011. Pengaruh Ethical Climates Pada Komitmen Organisasi Dengan Organizational -Professional Conflict Sebagai Variabel Intervening. Jurnal. Semarang : UNDIP

Schultz, J.J., Johnson, D.A., Morris, D. and Dyrnes, S. 1993. An investigation the reporting of questionable acts in an international setting. Journal of Accounting Research, Vol. 31 No. 1,pp. 75-103.

Semendawai, Abdul Haris, dkk. 2011. Memahami Whistleblower. Jakarta :Lembaga Peerlindungan Saksi dan Korban (LPSK).

Setyawati, Intan. 2015. Faktor-Faktor Yang Mempengaruhi Niat Melakukan Whistleblowing Internal (The Factor Influencing Internal Whistleblowing Intentions). Jurnal Ekonomi \& Bisnis ISSN: 16930908. Pekalongan : Universitas Pekalongan.

Siregar, Syofian. 2013.Metode Penelitian Kuantitatif. Jakarta : Prenadamedia Group.

Sugiyono.2016. Metode Penelitian Kuantitatif, Kualitatif, dan R\&D. Bandung : CV. Alfabeta.

Sukrisno, Agus . 2009. Etika Bisnis dan Profesi. Jakarta : Salemba Empat. 


\section{Jurnal Ilmiah Ekonomi dan Bisnis}

Vol. 15. No. 2, September 2018: 165-176

EISSN : $2442-9813$

Supranto. 2001. Statistik Teori dan Aplikasi, Cetakan Kedua. Jakarta: Penerbit Erlangga.

Thoifah,I'anatut. 2015. Statistika

Pendidikan Dan Metode

Penelitian Kuantitatif. Malang :

CV. Madani Media.

Wahyuningrum, C. H. 2009. Pengaruuh Komitmen Profesional dan

Komitmen Organisasi Terhadap Kepuasan Kerja Auditor : Motivasi Sebagai Variabel Intervening. Skripsi. Semarang : Universitas Negeri Semarang.

Yulianto, R. Dimas Arief. 2015. Pengaruh Orientasi Etika, Komitmen Profesional, dan Sensivitas Etis Terhadap Whistleblowing.(Studi Empiris pada Badan Pemeriksaan Keuangan (BPK) Perwakilan Daerah Istimewa Yogyakarta). Skripsi. Yogyakarta : Universitas Negri Yogyakarta. 